\title{
The Dual Penal State á la Markus Dirk Dubber
}

\author{
KIMMO NUOTIO *
}

Markus Dirk Dubber and Lindsay Farmer wrote in 2007: 'The critical, as opposed to legitimating, potential of criminal law historiography has yet to be fully realized. The same is true, if to a slightly lesser extent, of comparative studies of criminal law. ${ }^{1}$

The Dual Penal State is the book trying to deliver this. ${ }^{2}$ It is a book about the life of criminal law within the liberal legal-political project of the Western democracies. The title of the book pays a tribute to the book The Dual State ${ }^{3}$ by Ernst Fraenkel, the astonishing work of a practicing lawyer (and a theorist) which looks at the schizophrenic situation in the German legal order during the Hitler regime. From here Dubber borrows the idea that the state may have two different faces at the same time. The life and legal status of many Germans did not change radically when the National-Socialists gained the power, but the new laws effectively abolished the means of legal protection of some targeted groups. For the Poles (since 1941) and the Jews this shift was crucial. Instead of German criminal law a one-page administrative order was being applied. They were no longer subjects of laws, but only objects of laws and of the governance and policing that the laws enabled. This was the field for the so-called prerogative state to operate.

This duality is now being explored, in the context of penal state and the criminal law. The claim is that even in the criminal law of today we find traces of a similar duality. We

* Kimmo Nuotio, Professor of Criminal law, University of Helsinki. E-mail: kimmo.nuotio@ helsinki.fi.

1 Dubber and Farmer (eds.), Introduction: Regarding Criminal Law Historically in Modern Histories of Crime and Punishment (Stanford University Press 2007) pp. 1-13, at 5.

2 Markus D. Dubber, The Dual Penal State: The Crisis of Criminal Law in Comparative-Historical Perspective (Oxford University Press 2018), 296 pages.

3 See Fraenkel, The Dual State: A Contribution to the Theory of Dictatorship (Oxford University Press 2017). First published in 1941.

This is an Open-access article distributed under the terms of the Creative Commons Attribution 3.0 Unported License (http://creativecommons.org/licenses/ by/3.0/), permitting all use, distribution, and reproduction in any medium, provided the original work is properly cited. 
have the parts which are civilised, in which the suspects and convicts are being seen as citizens who have just done something wrong. But we also have the laws that go beyond, laws which focus on the dangerousness of certain individuals and which mainly seek to reduce the potential harm these individuals could do to others. This is where the sovereign power deals with a subordinate.

Dubber is known for his work on police which is seen as a particular mode of governance instead of only as a way of regulation. ${ }^{4}$ Police is about maintaining and restoring order. Historically, especially on the Continent, and as known in the German legal history, Polizei was a broad concept including a variety of matters relevant for running a society. The prince was responsible for maintaining law and order and the well-being of society and gave the necessary orders and ordinances accordingly. A special science, Polizeiwissenschaft, was created for that purpose. The dominant model of governance of the society was one that did not give much rights to the people subordinated to this exercise of authority and power. First the liberal-political project introduced a new concept of law. Rechtsstaat and Polizeistaat were the two ideal types of state.

The paradox and the crisis of today is that the states have failed to introduce civilised principles into their criminal justice, even though we know better and have known already for at least two centuries that we should rethink our criminal justice. This is the thread through the entire enterprise: to win a perspective that would enable us to make sense of this failure. A critical comparative-historical account is the method applied, the first step towards seeing where we are.

The book provides a rich comparative-historical study looking at legal materials of different levels: learned views, criminal law doctrines, practices. It seems that the brute fact of the failure has been obscured by the trust in developed legal doctrines and other scholarly achievements.

A special emphasis has been given to the role of criminal law scholarship and the ways in which it has contributed to the failure. Criminal law scholarship has provided for slogans and labels and has worked out taxonomies. In doing this, it has mainly provided services for the state power. And not only that: the scholars have even at times placed themselves above the legislature and the courts believing they possessed the truth about the world (the ontic) and/or about the role of human action in it. Claus Roxin's theory of participation in crime, especially the doctrine of Tatherrschaft, serves as an example. The development of the doctrine of complicity looks very different now, after we have got acquainted with the details and anecdotes.

The tension between the two modes of governance is being looked at both in a comparative and historical perspective. The German law and the law of the United States are

4 See Dubber, The Police Power: Patriarchy and the Foundations of American Government (Columbia University Press 2005). 
the cases chosen for a closer look. The author masters well the materials needed in this study. The study is rich in detail and illustrates the more general insights rather well. The text also preserves the necessary distance to the matters it deals with. A critical tone dominates, and the many small stories are fun to read.

In my view, the case of German penal state is even the more interesting one out of the two, since there have been more efforts to proceed towards a civilised and inclusive approach. But, it becomes clear, what the study suggests is not an account which celebrates the successes of German criminal law. Rather, we learn that the progress, if we can use this term, has not been linear and that the self-description delivered by the scholars has not always been trustworthy. The presentation of the German case reveals the self-sufficiency of the criminal law professors believing that their scholarship has been in the lead as regards the general development of criminal law (and could even serve as a model for the world). The critical comparative-historical approach opens up the legal materials and the many well-known stories and histories, for a fresh look.

The book provides many wonderful examples of how easily we trust that our views are superior to the views of others. The German discussion around the famous Dudley vs. Stephens case is not only amusing, but also telling.

We learn that the German legal history, even the more recent one, is far from only being a story about progress and a science-led march towards the perfection of a Rechtsstaat. For instance, the progressive school which had Franz von Liszt as the portal figure called for an approach that would be legalistic in its emphasis on the nullum crimen sine lege principle. At the same time, however, the criminals were ranked according to their dangerousness. This school of thought presented itself as science and inspired the creation of particular measures for the dangerous habitual offenders. A two-track model of criminal justice was introduced in Germany in 1933; the same year as the Nazis came into power. And it has continued to exist ever since.

The duality of law and police is being dealt with extensively, and it becomes clear that it is not meant to be a rigid scheme. A dualistic analysis recognises multiple perspectives and affirms the possibility of shifts and counter-narratives. Not even is penal law always more legitimate than penal police. I find it helpful that the distinction (a label as such) will not be used categorically. But, one has to admit, one pays the price of losing clarity. Namely, if the classification tells only part of the story, how important is it to use it? One explanation may be that the different critical analyses reach different levels. A genealogical analysis seems to reach the deepest since it enables finding continuities.

A lot of attention has been given to explain the methodological approach adopted in the book. It is genealogical, looking at the long lines of development. And in doing this it is both descriptive and normative. Dubber clearly wishes to develop the tools that would enable us to identify what type of governmentality the various penal laws in fact represent. The positivist-statist approach so typical of most of the criminal law scholar- 
ship does not suffice. The aim is to challenge the ways penal power is being applied in our states.

It all begins of course with the Enlightenment philosophy which introduced the liberal ideals, a new type of view on criminal law. Paul J.A. Feuerbach for example claimed that only violations of individual rights should be termed criminal wrong and deserved to be made punishable. This meant that criminal law should be marked as a field separate from other regulations concerning maintaining of order. Feuerbach criticised the fusion of penal law with other regulation and sanctioning of dangerous and harmful activities.

The founding fathers of the critical Enlightenment tradition of course also included other scholars, such as Cesare Beccaria and Jeremy Bentham. A close reading shows that not even the founding fathers were always that opposed to cruel punishments.

However, it was precisely this Enlightenment thinking which introduced a new idea of law and legality, and the radical idea that the practices of criminal justice are not just household issues of maintaining order. From now on, the state punishment would need a justification without which it itself would turn out to be an act of violence, even a crime. This quest for justification is what renders necessary the development of a penal order which recognises that the origin of criminal law resides in the people, not in the person of the ruler. According to the democratic ideals, people should have a say on what deserves to be made punishable. People should be seen as holders of rights, as subjects, or subject-objects. Their autonomy should be protected and heteronomy should be avoided. Criminal law should serve the interest to protect freedom.

This is not the first time that a study involves similar critical premises. Scholars of the so-called Frankfurt school of criminal law (if such a name can be used), such as Wolfgang Naucke, Winfried Hassemer and Felix Herzog, have shared the claim that the legitimacy of criminal law should not be taken for granted. ${ }^{5}$ Dubber does not very openly relate his approach to other existing critical traditions. We might conclude that the methodology developed and applied is new, at least in this form. The methodological reflections are, indeed, an important part of the study.

Sure, a broad comparative-historical study of this kind should be a novelty. The study does not suggest that we should just go back to Feuerbach and other classics and measure the legitimacy of current laws and practices against a framework dating back more than 200 years. There is no easy way forward. It may thus be better not to specify openly, what the legitimacy conditions actually are today. Using the comparatist's tools may be one way forward. We should also of course take into account the development of our societies. The penal states are today active on many other fronts than just theft and murder. Economic crime, organised crime, environmental crime, etc, also require attention.

See Jahn and Ziemann, Die Frankfurter Schule des Strafrechts: Versuch einer Zwischenbilanz, 69(19) Juristenzeitung (2014) pp. 943-947, at 947. 
Questions concerning this are, however, not really within the scope of the book, which follows the historical lines.

Much of the material used in this book is rather well-known to scholars working in this field, be it the German or U.S. law side. The novelty is in the way internal links are created and contexts built, and we begin seeing the material in a new light. The author does not seem to appreciate highly the doctrinal and conceptual products of legal research, something which he aptly calls taxonomic activity. Legal science may be important, but unfortunately the science has more often than not neglected the deeper underlying questions of legitimacy. In systemic doctrinal analysis legitimacy is often rather presumed than assessed and contested.

If Dubber does not let German law easily off the hook, the story of the U.S. penal state is still much darker. It seems that there never was even an understanding that a liberal-political project could and should be adopted. In the U.S. criminal law the traits of enemy criminal law, to use the term coined by the German scholar Günther Jakobs, have been present from the very beginning, and there are very few signs of moves towards citizen criminal law approach. U.S., which presents itself as the global champion of rule of law, democracy, and individual rights cannot according to Dubber 'consistently continue to avoid facing up to the most awesome challenge to the legitimacy of state power: state punishment'.

The study looks not only at what really has happened, but it even has an eye for what did not happen but maybe could or should have happened. The story of U.S. penal state is a story of unused opportunities. On the Continent the codifications and the reforms of penal codes have ensured that at least some of the ideas that the scholars were discussing were considered and implemented in practice. The U.S. story rather tells that the dominant paradigm of the penal state has been a penal police state, from the very beginning until these days. There is a long continuum from the slavery to the dealing with criminals. Criminals were always outlaws with very limited rights, a view that was never really challenged. 'There was no American Beccaria, no American Bentham, no American Feuerbach.7 A liberal legal-political project was present in the U.S, but for some reason the project never addressed criminal law.

The crucial moment in the history of U.S. criminal law was when the Model Penal Code was drafted in the 1950's. But even that occasion was missed since the drafters were drawing on the European heritage but not on the liberal one. Rather, they introduced the treatment ideology which stressed the goals of individual prevention and incapacitation. Therefore, the Model Penal Code did not change the legal landscape and introduce a

$6 \quad$ Dubber, The Dual Penal State: The Crisis of Criminal Law in Comparative-Historical Perspective (Oxford University Press 2018), p. 223.

Dubber, Ibid, p. 179. 
more inclusive penal law policy, but it rather confirmed the opposite. Even the term 'punishment' was being replaced by more scientific terms such as 'treatment' and 'correction'. This will come as a surprise to many.

Later, the war on crime started by Nixon brought about its excesses. The scandal manifests itself not only in the massive overuse of prisons and humiliating punishments, but also in the racial discrimination of these excessive practices, which were targeting and penalizing entire communities.

The American Law Institute has recently, in 2017, completed the revision of the provisions of the Model Penal Code on sentencing. This fact might have deserved a mention since the reason for this work is precisely the need to introduce a more principled approach for sentencing and thus to address the excesses of the doctrines of treatment and incapacitation. ${ }^{8}$ Dubber has, however, dealt with this reform in his commentary on the Model Penal Code. ${ }^{9}$

The analysis is meant to be systemic, and it is. It is aimed to serve an understanding of the paradoxes the liberal legal-political project has been facing and is still facing in those countries considered to celebrate such Western values. A revealing critique is needed for us to see where we stand now. First the can we begin discussing what to do about it. Even though the emphasis is on criticism, I read between the lines and found at least some modest promise of the fact that we could do better, if we only would be mindful of the values that should inform liberally minded penal states, their citizens, and the scholars working on these issues. The road will, however, probably be long and winding, since the history tells that most efforts to introduce science into the field of penal law have not meant any improvement. In fact, criminal law science and its scientific helpers have contributed to the current state of affairs.

What would the next step be? Dubber would welcome an inclusive conception of 'legal science': ${ }^{10}$

Perhaps a modest, unpretentious, and inclusive conception of "legal science" can emerge, one that implies a commitment to systematic and comprehensive inquiry into internal coherence and consistency within a given regime of penal norms as well as into the regime's external consistency with whatever commitments the modern liberal legal-political project places on the legitimate use of state power in general, and state penal power in particular.

$8 \quad$ See Model Penal Code: Sentencing. Proposed Final Draft (April 10, 2017); See also Reitz, Model Penal Code, Plan for Revision, 6(1) Buffalo Criminal Law Review (2002) pp. 525-672.

9 See Dubber, An Introduction to the Model Penal Code, 2nd ed. (Oxford University Press 2015).

10 Dubber, Ibid., pp. 229-230. 
This suggestion clearly entails a program. Someone might say that this we could do maybe even without first engaging in a critical comparative-historical analysis. We might, however, respond that only through a critical analysis we may be able to identify the moments when we did wrong and accepted a too positivist and state-centred perspective. The strive for internal coherence and consistency is in fact nothing new, since this is what doctrinal analysis of criminal law has always been. The aim to secure also external consistency implies opening up to broader issues, involving an active relationship with constitutional law, extends to issues concerning the legitimacy of use of state powers more in general.

No doubt this book is an important read for anyone wishing to understand the major developments and the paradoxes of these. In fact, the telling of stories to illustrate the main tension between the two modes of governance is highly inspiring. To give an example: if one's background is from another penal state than the two ones already dealt with, but still within the scope of the general liberal project, one simply begins to picture the story of one's own penal law in the light of the duality. The story of Nordic criminal law, for instance, would be worth telling.

The fact that a theory invites to such a use is evidence of the intellectual force in this dualistic way of looking at the penal laws and penal systems of the states. Broadening the application of this approach to other states would also serve well the aim of increasing the knowledge of the failures, successes and paradoxes of the use of penal power in a broader comparative setting.

Overall, the book emphasises the critical analysis of the sloganism, labelism and other methods used in the criminal law scholarship. To give an example, positive general prevention in its different versions is being treated under the title of sloganism. It has not been recognised as anything of general importance, but as 'a parochial answer to a parochial question.' ${ }^{\prime 1}$ This conclusion may be hasty.

Surely, we cannot really prove empirically the positive general preventive effect. But it seems clear that, according to this theory, people are being addressed as responsible citizens, and not as enemies or as rational calculators who would breach the law if they saw benefits in doing so. Isn't this precisely what citizens' criminal law should look like? If we make use of this theory, overtly harsh punishments seem problematic in the first place.

Almost the same could be said about the discussion of another label, the Rechtsgutslehre, the idea that knowing the protected interest would be helpful in deciding on the limits of criminal law and in applying the criminalisations in concrete cases. For sure, we should not expect miracles. But being clear about what we are doing and what we are aiming at will sharpen our eyes anyway, and some sort of a discussion of the aims and the 
interests we are protecting will in any case will be part of any workable theory or model of legitimate use of criminal law.

Compared to the critical review of a host of core concepts and doctrines, it remains much more open what a general liberal theory of a legitimate use of criminal law would look like. Maybe we rushed precisely at the moments when we should have slowed down and looked for something helpful to bring along?

We continue to be shocked by finding traces of enemy criminal law as pointed out by Günther Jakobs. For Dubber this is not shocking, but rather proves his thesis. Of course we should search for options to build on the liberal values and the citizens' perspective. The paradox is, however, that the political setting in which criminal policy issues are being addressed today is in fact coloured by cries for tougher punishments. This is not the music of Enlightenment. In the field of anti-terrorist measures we could point out many more examples of truly exclusionary enemy criminal law. Dubber emphasises that his project has both a descriptive and a normative agenda. The normative agenda seeks to address the issue of whether legitimate criminal law is possible in a liberal state and, if so, what a liberal account of criminal law would look like. ${ }^{12}$

How to reduce the role of enemy criminal law? One effort could obviously be to simply try to elaborate principles for criminalisation, principles for the use of threat of punishment and for sentencing in order to prevent excesses and to make sure that at least some liberal values are being appreciated. The classical legal principles of legal certainty and the like do not protect against harsh punishments if the core references in harshness are problematic, like in the case of U.S. criminal policy. We would have to understand and prove that a civilised criminal justice would simply seek to avoid punishments that are overtly harsh as a matter of principle, even if there would be some costs in not being harsh. But clearly this is not enough.

If we wish to elaborate on a theory of how to live up to a promise of civilised criminal justice, one which takes the promise raised by Enlightenment seriously, it is important first to recognise the set of values that would correspond to such an expectation. Then, maybe we could see how the 'best practices' in the various penal states have tried to make them real. The U.S. has put the emphasis on the criminal procedure, whereas the German tradition places most weight on substantive criminal law. A comparative perspective may have to look at both.

Comparative legal scholarship may indeed be needed to contribute here. We, the scholars, as participants in a comparative and transnational dialogue need to 'step outside the comfort of the domestic doctrinalism. ${ }^{13}$ Certainly, we will first have to win the necessary distance to the legal systems within which we have been working. We need a new

12 Dubber, Ibid., p. 174.

13 Dubber, Ibid., p. 64. 
perspective for our work. A real transnational dialogue concerning a liberal criminal law cannot succeed if we are all just marketing our own achievements. And we would have to look at more jurisdictions to get a richer picture.

The conclusion many would subscribe to is that we need more than ever a critical but constructive analysis to reduce the gap between the promise of the liberal legal-political project and the current illiberal state of affairs. We would need an account of criminal law which would be rechtsstaatlich in its spirit but which would be adjusted to the modernised societies. Even a penal-welfare state needs to be based on liberal values. Here we find a similarity to what Lindsay Farmer has been suggesting in his historically founded work on how criminal law protects the civil order. ${ }^{14}$

Most crucial it would be to develop a way of thinking which is informed by comparative-historical analyses and would learn from history, but which we could apply today. Critical criminal law historians, comparatists and criminal law scholars would have to team up. We cannot borrow directly from history as regards the constructive part of the work needed. We cannot produce a normative theory of criminal law which would give definite answers, but the question must be: what kind of criminal law do we want, and in what kind of society do we wish to live?

In fact, I would have expected to find more about this reconstructive project. In the book, everything which resembles welfarist policies seems to fall under the category of penal police state. As for Franz von Liszt and the defense of the society against dangerous individuals this may be a justified conclusion, as we learn through many examples. These days we have also many new phenomena which even could merit appraisal as compatible with a liberal approach. The development of community sanctions, and even practices of victim-offender mediation could serve as examples. We should not be misled by a too classical use of our dual categorisation. In fact, this is a risk when using a historical approach. We should include an analysis of contemporary phenomena as well.

The Dual Penal State operates on the critical side, and the message is clear: we need to continue working, day by day, to learn to manage the tension between heteronomy and autonomy, the tension which cannot be eliminated. It is the work of Sisyphus.

Dubber has made an important contribution in starting the debate about the problem and even outlining his suggestions on how to proceed. He is suggesting a transnational, global dialogue on these issues. This would be the task of a non-parochial discipline of criminal law. The (critical) criminal law scholars should see this as a call to share insights and deliver models. The critical comparative-historical methodology could be helpful in getting the much needed dialogue underway. Dubber has elsewhere explained more in detail what the New Legal Science as a global discipline would look like. The aim is to

14 See Farmer, Making the Modern Criminal Law: Criminalization and Civil Order (Oxford University Press 2016). 
build a critical and contextual legal science which would, i.a., overcome the distinction between common law and continental law and which would study critically the way a state uses its power. ${ }^{15}$ As a part of the project, we may also still need to continue discussing the methodologies themselves. A dual state analysis might still need to be enriched.

The book is a good read not only for legal comparatists or legal historians, but also for the criminal law scholars themselves. For them (for us) it really gives food for thought by showing the well-known materials in a new light.

15 See Dubber, New Legal Science: Toward Law as a Global Discipline (June 2014). https://ssrn. com/abstract=2462224 [last visited 17 January 2019]. 